\title{
PENYULUHAN PENTINGNYA PENINGKATAN VO2MAX GUNA MENINGKATKAN KONDISI FISIK PEMAIN SEPAKBOLA FORTUNA FC KECAMATAN RANTAU RASAU
}

\author{
Boy Indrayana \\ Ely Yuliawan \\ Fakultas Ilmu Keolahragaan, Universitas Jambi \\ boy_indrayana@unja.ac.id
}

\begin{abstract}
ABSTRAK
Tujuan kegiatan Pengabdian Pada Masyarakat ini adalah memberikan pengetahuan kepada Pelatih dan para pemainnya tentang pentingnya peningkatkan VO2Max sehingga dapat meningkatkan Kondisi Fisik yang lebih baik lagi bagi para pemain tersebut. VO2Max adalah volume Oksigen maksimal yang diproses oleh tubuh manusia pada saat melakukan kegiatan yang intensif. VO2 max ini adalah suatu tingkatan kemampuan tubuh yang dinyatakan dalam liter per menit atau milliliter/menit/kg berat badan.VO2Max biasanya digunakan untuk mengukur daya tahan atlet dalam melakukan suatu cabang olahraga.

Seorang pemain sepakbola dengan nilai VO2MAX semakin tinggi, maka semakin bagus staminanya. Begitupun sebaliknya semakin rendah nilainya, semakin jelek stamina seorang pemain. Melihat akan pentingnya kebutuhan tersebut sangatlah diperlukan melaksanakan sosialisasi ini kepada pelatih dan pemain sepakbola di Klub Sepakbola Fortuna FC. karena sejauh ini belum pernah ada yang melakukan sosialisai ini sehingga dari kegiatan ini akan menghasilkan ilmu baru bagi para pelatih dan para pemain sepakbola.
\end{abstract}

\section{Kata kunci : VO2Max, Kondisi Fisik}

\section{PENDAHULUAN}

Kondisi fisik adalah satu prasyarat yang sangat diperlukan dalam usaha peningkatan prestasi seorang atlet, bahkan dapat dikatakan sebagai keperluan dasar yang tidak dapat ditunda atau ditawar lagi. Kondisi fisik atlet memegang peranan yang sangat penting dalam program latihannya. Program latihan kondisi fisik haruslah direncanakan secara baik dan sistematis dan ditujukan untuk meningkatkan kesegaran jasmani dan kemampuan fungsional dari sistem tubuh sehingga dengan demikian memungkinkan atlet untuk mencapai prestasi yang lebih baik.

Kondisi fisik dan komponenkomponen kondisi fisik merupakan satu kesatuan utuh dari komponen yang tidak dapat dipisahkan, baik peningkatannya maupun pemeliharannya. Artinya bahwa setiap usaha peningkatan kondisi fisik, maka harus mengembangkan semua komponen tersebut. Komponen kondisi fisik meliputi, kekuatan (strength), daya tahan (endurance), daya ledak (muscular power), kecepatan (speed), daya lentur (flexibility), koordinasi (coordination), keseimbangan (balance), ketepatan (accuracy), reaksi (reaction). Dalam permainan sepakbola, komponen kondisi fisik yang dominan adalah daya tahan (endurance), daya ledak otot tungkai (explosive power), kecepatan (speed) dan kelincahan (agility).

Daya tahan merupakan kemampuan dan kesanggupan tubuh untuk melakukan aktivitas olahraga dalam waktu yang lama tanpa mengalami kelelahan yang berarti. Para pemain dituntut untuk memiliki tingkat daya tahan yang baik. Tuntutan itu didasarkan kepada tugas dan tanggung jawab sebagai pemain sepakbola yang harus terus bergerak. Untuk memperbaiki VO2Max bisa kita lakukan dengan olahraga atau latihan. Dengan latihan daya tahan yang sistematis, akan memperbaiki konsumsi oksigen maksimal dari 5\% sampai $25 \%$. Proses berlatih yang dilakukan secara teratur, terencana berulang-ulang dan 
semakin lama semakin bertambah bebannya, serta dimulai dari yang sederhana ke yang lebih kompleks(Sistematis dan Metodis).

\section{TARGET LUARAN}

Target : seluruh pemain dan pelatih mengikuti kegiatan sosialisasin ini sehingga mereka sadar akan kebutuhan VO2Max yang baik akan menghasilkan pretasi yang baik juga

Luaran : Setelah dilaksanakan sosialisasi ini diharapkan pelatih bisa mengaplikasikan ide-ide baru dalam memberikan latihan yang dikemas menarik dan bervariasi agar pemain serius melakukan pemanasan.

\section{METODE PELAKSANAAN}

Pelaksanaan kegiatan ini menggunakan prosedur kerja agar sasaran dan harapan yang akan dilakukan dapat terlaksana dengan baik. Berikut adalah prosedur kerja yang kami susun untuk kegiatan "Penyuluhan pentingnya peningkatan VO2Max guna meningkatkan Kondisi Fisik pemain Sepakbola Fortuna FC Kecamatan Rantau Rasau" :

1. Melakukan survey ke klub sepakbola untuk melakukan kegiatan penyuluhan.

2. Memastikan bahwa seluruh para pemain dan pelatih agar mengikuti kegiatan penerapan.

3. Melakukan kegiatan Penyuluhan pentingnya peningkatan VO2Max guna meningkatkan Kondisi Fisik pemain Sepakbola Fortuna FC Kecamatan Rantau Rasau

\section{Langkah-langkah kegiatan}

1. Menyampaiakan izin kepada Pihak Klub untuk melakukan kegiatan penyuluhan.

2. Mendata jumlah atlet dan pelatih yang mengikuti kegiatan penyuluhan.

3. Melakukan penyuluhan berupa penyampaian materi terkait pentingnya meningkatkan VO2Max dan Kondisi Fisik para pemain.

\section{KELAYAKAN PERGURUAN TINGGI}

Kegiatan pengabdian pada masyarakat merupakan kegiatan rutin yang dilakukan oleh LPPM UNJA. Pengabdian masyarakat merupakan salah satu bagian Tri Dharma Perguruan Tinggi. Sebagai Universitas yang cukup besar di Sumatera terutama dalam disiplin ilmu yang dimiliki, begitu juga FIK Fakultas baru yang mempunyai dua program studi yaitu pendikan olahraga dan kesehatan dan Kepelatihan olahraga yang sangat relevan dengan bidang yang akan dilakukan, disamping itu juga mempunyai empat orang Doktor Olahraga dan dua orang Doktor sedang menyelesaikan program Doktornya, dan semua dosen yang mengajar sudah mempunyai predikat Magister, inilah yang menjadi kekuatan dan kelayakan Universitas Jambi dalam melakukan pengabdian dibidang Olahraga.

Kurikulum yang ada di Fakultas Ilmu Keolahragaan menyajikan bagaimana menjadi pelatih olahraga yang dibekali dengan kemampuan aktivitas olahraga dan pemahaman bagaimana memaksimalkan kinerja dalam kepelatihan. Ini selaras dengan kurikulum kepelatihan Olahraga. penerapan ini akan sangat berarti demi menciptakan ide ide baru dalam pembinaan khusus nya dalam sepakbola.

\section{MATERI YANG DIBERIKAN Volume Oksigen Maximal (VO2Max)}

Secara teknis, pengertian istilah kardio (jantung), vaskuler (pembuluh darah), dan aerobik (bekerja dengan oksigen), memang berbeda, tetapi istilah itu berkaitan erat satu dengan lainnya. Kebugaran aerobik atau kebugaran kardiorespirasi merupakan kumpulan kemampuan jantung untuk memompa darah yang kaya oksigen ke bagian tubuh lainnya dan kemampuan untuk menyesuaikan serta memulihkan dari aktivitas olahraga.

Kebugaran kardiorespirasi merupakan salah satu komponen terpenting dari kebugaran jasmani. Dengan memiliki kebugaran kardiorespirasi, seseorang dapat melaksanakan aktivitas keseharian tanpa mengalami kelelahan yang berarti, disamping itu jantung dan paru-paru dapat berfungsi secara optimal, sehingga penyakit jantung dapat dihindari. Daya tahan kardiorespirasi merupakan indikator yang tepat untuk menggambarkan status kebugaran jasmani seseorang. Daya tahan jantung paru adalah kapasitas sistem jantung, paru-paru, dan pembuluh darah untuk berfungsi secara optimal saat 
melakukan aktivitas sehari-hari dalam waktu yang relatif lama tanpa mengalami kelelahan yang berarti.

$\begin{array}{crr}\text { Kebugaran } & \text { sistem } & \text { pernafasan } \\ \text { jantung } & \text { (cardiorespiratory) } & \text { adalah }\end{array}$ efektivitas jantung dan paru-paru dalam mengalirkan darah, oksigen dan zat makanan ke jaringan tubuh selama kegiatan fisik berlangsung. Daya tahan kardiorespirasi adalah kemampuan jantung mensuplay oksigen untuk kerja otot dalam jangka waktu lama. Daya tahan paru jantung atau daya tahan kardiorespirasi adalah keadaan dimana jantung seseorang mampu bekerja dengan mengatasi beban berat selama suatu kerja tertentu.

Kapasitas aerobik maksimal dinyatakan sebagai VO2 Max. Kapasitas aerobik pada hakikatnya menggambarkan besarnya kemampuan motorik (motoric Power) dari proses aerobik pada seorang atlet. Kapasitas volume oksigen maksimal (VO2 Max) adalah tempo tercepat dimana seseorang dapat menggunakan oksigen selama olahraga. Makin besar kapasitas $V O 2$ Max akan makin besar pula kemampuannya untuk memikul beban kerja yang berat dan akan lebih cepat pulih kesegaran fisiknya sesudah kerja berat tersebut selesai.

VO2 Max yang besar berbanding lurus dengan kemampuan seorang olahragawan memikul beban kerja yang berat dalam waktu yang relatif lama. Hal ini disebabkan kapasitas aerobik yang dimiliki seorang olahragawan sangat terbatas, sehingga sulit untuk bertahan dalam memikul beban kerja/ latihan yang berat dengan hanya mengandalkan sistem anaerobik saja yaitu tanpa menggunakan oksigen apalagi dalam waktu yang cukup lama. Oleh sebab itu sistem aerobik yang bekerja hanya dengan pemakaian oksigen merupakan kunci penentu keberhasilan dalam olahraga ketahanan. VO2 Max yang besar juga juga mempercepat pemulihan setelah beraktivitas.

Telah dijelaskan diatas bahwa $\mathrm{VO} 2$ Max yang tinggi memungkinkan untuk melakukan pengulangan gerakan yang berat dan lebih lama, dibandingkan bila VO2 Max nya rendah. Untuk dosis aktivitas yang sama, maka VO2 Max yang lebih tinggi akan menghasilkan kadar asam laktat yang rendah. Hal ini menjadi salah satu penyebab kenapa seseorang yang memiliki VO2 Max yang tinggi lebih cepat pemulihannya setelah beraktivitas/ latihan jika dibandingkan dengan seseorang yang $\mathrm{VO} 2$ Max nya rendah.

Suatu pemulihan yang cepat akan membawa seseorang untuk mengurangi interval istirahat dan melakukan pekerjaan dengan intensitas yang lebih tinggi. Ini sebagai hasil dari interval istirahat yang pendek (cepatnya pemulihan) sehingga jumlah repetisi dapat dinaikkan, dan ini merupakan suatu tambahan dalam volume latihan. bagaimanapun juga VO2 Max mengandalkan pada sistem respirasi dan pernapasan yang benar. Pernapasan memainkan peranan yang sangat penting dalam latihan daya tahan terutama pada olahraga yang membutuhkan waktu yang cukup lama dengan sejumlah pengulangan keterampilan tinggi.

VO2Max adalah volume oksigen maksimum yang dapat digunakan permenit. VO2Max adalah kecepatan pemakaian oksigen dalam metabolisme aerob maksimum. VO2Max merupakan daya tangkap aerobik maksimal menggambarkan jumlah oksigen maksimum yang di konsumsi per satuan waktu oleh seseorang selama latihan atau tes, dengan latihan yang makin lama makin berat sampai kelelahan, ukurannya disebut VO2max.

Volume $\mathrm{O} 2$ max dengan demikian adalah suatu tingkatan kemampuan tubuh yang dinyatakan dalam liter per menit atau milliliter/menit/kg berat badan. Setiap sel dalam tubuh manusia membutuhkan oksigen untuk mengubah zat makanan menjadi ATP (adenosine triphosphate) yang siap dipakai untuk kerja tiap sel, yang paling sedikit mengkonsumsi oksigen adalah otot dalam keadaan istirahat. Sel otot yang berkontraksi membutuhkan banyak ATP, akibatnya otot yang dipakai dalam latihan membutuhkan lebih banyak oksigen dan menghasilkan $\mathrm{CO} 2$ dan $\mathrm{H} 2 \mathrm{O}$.

\section{Cara Melatih VO2max}

Melatih VO2max ada beberapa hal yang harus diperhatikan, latihan harus menggunakan otot-otot besar tubuh secara intensif (terus-menerus) dalam durasi yang 
relative lama. Latihan yang baik untuk meningkatkan VO2max adalah jenis latihan cardio atau aerobic, latihan yang memacu detak jantung, paru dan sistem otot. Latihan harus berlangsung dalam durasi yang relative lama namun dengan intensitas sedang

Sejumlah penelitian menunjukan bahwa meningkatkan VO2max dapat dengan latihan pada intensitas detak jantung $65 \%$ sampai $85 \%$ dari detak jantung maksimum, selama setidaknya 20 menit, frekuensi 3-5 kali seminggu (rikimakaro.blogspot.com). Contoh latihan yang dapat dilakukan adalah lari diselingi jogging jarak jauh, fartlek, circuit training, cross country, interval training, atau kombinasi dan modifikasi dari latihan tersebut.

\section{Faktor-faktor yang mempengaruhi VO2max}

Faktor-faktor yang mempengaruhi VO2max diantaranya adalah:

a) Jenis kelamin: setelah masa pubertas wanita dalam usianya yang sama dengan pria pada umumnya mempu nyai konsumsi oksigen maksimal yang lebih rendah dari pria,

b) Usia: pada usia 13-19 tahun perkembangan VO2max anak akan lebih cepat karena hormon pertumbuhan lebih tinggi dibandingkan usia diatas 19 tahun,

c) Keturunan: seseorang yang memiliki keturunan dari orang tua yang memiliki kapasitas paru-paru yang besar maka akan menurun ke generasi selanjutnya,

d) Ketinggian: semakin tinggi tempat latihan maka tekanan oksigen yang ada semakin sedikit sehingga apabila berlatih pada dataran tinggi akan berbeda dengan berlatih pada dataran rendah,

e) Latihan: jenis latihan akan mempengaruhi perbedaan peningkatan VO2max,

f) Gizi: kualitas gizi yang baik akan mempengaruhi kualitas latihan.

Faktor lain penentu VO2max antara lain: (a) kapasitas paru: semakin tinggi volume paru, akan semakin mudah darah $(\mathrm{Hb})$ dalam mengikat oksigen dan melepaskan carbon dioksida di paru, (b) kadar $\mathrm{Hb}$ : kadar $\mathrm{Hb}$ akan berfungsi untuk mengikat oksigen, yang kemudian diedarkan ke jaringan seluruh tubuh, (c) kualitas dan elastisitas pembulu darah: pembuluh darah yang bersih dan elastis akan menentukan kualitas sirkulasi darah, (d) jantung: jantung yang mempunyai volume atau ruang yang besar pada atrium maupun ventrikel akan menghasilkan volume denyut yang lebih besar, (e) besar dan jumlah mitokondria: mitokondria sebagai tempat untuk berlangsungnya siklus krebs dan sistem transport elektron atau posporilasi oksidatif. Semakin banyak dan besar mitokondria pada setiap sel otot, maka penggunaan oksigen untuk membuat ATP akan dapat semakin cepat.

VO2 Max seseorang dipengaruhi oleh beberapa faktor lain:

1) Fungsi paru jantung, orang tidak dapat menggunakan oksigen lebih cepat daripada sistem paru-jantung dalam menggerakkan oksigen ke jaringan yang aktif, jadi kapasitas fungsional parujantung adalah kunci penentu dari $\mathrm{VO} 2$ Max. Namun fungsi paru-jantung lainnya seperti kapasitas pertukaran udara dan tingkat hemoglobin darah dapat membatasi VO2 Max pada sebagian orang.

2) Metabolisme otot aerobik, selama latihan oksigen benar-benar dipakai dalam serabut otot yang berkontraksi aktif, jadi VO2 Max adalah gambaran kemampuan otot rangka untuk menyadap oksigen dari darah dan menggunakannya dalam metabolisme aerobik.

3) Kegemukan badan, jaringan lemak menambah berat badan tetapi tidak mendukung kemampuan olahragawan untuk secara langsung menggunakan oksigen selama olahraga berat.

4) Keadaan latihan, kebiasaan kegiatan dan latar belakang latihan olahragawan dapat mempengaruhi nilai VO2 Max.

5) Keturunan, meskipun VO2 Max dapat ditingkatkan melalui latihan, kebanyakan penelitian menunjukkan bahwa besarnya peningkatan itu terbatas dari $10-20 \%$ gambaran ini menganggap rendah peningkatan yang terjadi dalam program jangka panjang untuk latihan dengan intensitas tinggi, meskipun demikian 
jelas bahwa VO2 Max seorang olahragawan perorangan dapat berbeda karena perbedaan garis keturunan.

\section{Latihan}

Latihan adalah suatu upaya sesorang mempersiapkan dirinya untuk tujuan tertentu. Latihan merupakan suatu proses atau, diungkapkan dengan kata lain, suatu periode waktu yang berlangsung beberapa tahun, hingga olahragawan mencapai standar puncak prestasi.

Latihan adalah proses sistematis dari berlatih atau bekerja yang dilakukan secara berulang-ulang dengan kian hari kian menambah jumlah beban latihan atau pekerjaannya, artinya, latihan harus dilakukan secara berencana, menurut jadwal, pola, dan standar tertendu, metodis, dari mudah ke sukar, latihan yang teratur, dari yang sederhana ke yang lebih kompleks. Adapun yang dimaksud berulang-ulang adalah agar gerakan-gerakan yang semula sulit dilakukan menjadi semakin mudah, otomatis, dan efektif pelaksanaanya sehingga semakin menghemat energi. Istilah latihan berasal dari kata dalam bahasa Inggris yang dapat mengandung beberapa makna berarti: practice, exercises, dan training. Dalam istilah bahasa Indonesia kata-kata tersebut semuanya mempunyai arti yang sama yaitu latihan. Namun dalam bahasa Inggris setiap kata tersebut memiliki arti yang berbeda-beda.

1) Practices aktifitas untuk meningkatkan kemahiran berolahraga dengan menggunakan berbagai peralatan dengan tujuan dan kebutuhan cabang olahraganya. Contoh dari practices adalah seorang pemain bola agar dapat menguasai menggiring bola secara penuh maka diperlukan practices dalam menggiring bola.

2) Exercises adalah perangkat utama dalam proses latihan harian untuk meningkatkan kualitas sistem organ tubuh manusia, sehingga mempremudah olahragawan dalam penyempurnaan geraknya. Latihan exercises biasanya disusun pelatih dalam satu sesi latihan yang berisi (1) pengantar latihan, (2) pemanasan, (3) latihan inti, (4) latihan tambahan, (5) pendinginan.
3) Training adalah penerapan dari suatu perencanaan untuk meningkatkan kemampuan olahraga yang berisikan materi olahraga teori, praktek, metode, dan aturan pelaksanaan sesuai dengan tujuan dan sasaran yang akan dicapai. (Sukadiyanto, 2011:5-6)

b. Tujuan latihan dan sasaran latihan

Menurut Sukadiyanto (2011:8-9) tujuan latihan secara umum adalah untuk membantu guru, pelatih, dan pembina olahraga agar dapat menerapkan kemampuan konseptual serta keterampilan dalam membant mengungkap potensi olahragawan mencapai prestasi puncak. Sasaran latihan secara umum adalah untuk meningkatkan kemampuan dan kesiapan olahragawan dalam mencapai puncak prestasi.

Adapun sasaran dan tujuan latihan secara garis besar adalah untuk meningkatkan:

1) Meningkatkan kualitas fisik dasar secara umum dan menyeluruh.

2) Mengembangkan dan meningkatkan potensi kualitas fisik khusus.

3) Menambah dan menyempurnakan tehnik.

4) Mengembangkan dan menyempurnakan strategi, taktik, dan pola bermain.

5) Meningkatkan kualitas dan kemampuan psikis olahragawan dalam bertanding.

c. Prinsip latihan

Setiap atlet memiliki sifat manusia yakni : Multidimensional potensi yang berbeda-beda, labil, dan mampu beradaptasi sehingga memerlukan latihan untuk meningkatkan dan mengembangkan potensi tersebut dengan latihan Djoko Pekik (2002:42). Berdasarkan sifat manusia itulah ada beberapa yang perlu diperhatikan dalam proses berlatih-melatih yaitu :

1) Prinsip beban lebih (Overload)

Pendapat Fox (1993:687) bahwa intensitas kerja harus bertambah secara bertahap melebihi ketentuan program latihan merupakan kapasitas kebugaran yang bertambah baik. Menurut Bompa (1994:29) bahwa pemberian beban latihan yang melebihi kebiasaan kegiatan sehari-hari secara teratur. Hal itu bertujuan agar sistem fisiologis dapat menyesuaikan dengan tuntutan fungsi yang dibutuhkan untuk 
tingkat kemampuan tinggi. Apabila tubuh ditantang dengan latihan beban berat maka akan terjadi proses penyesuaian. Penyesuaian tersebut tidak saja seperti pada kondisi awal namun secara bertahap mengarah ketingkat yang lebih tinggi yang disebut superkompensasi. Superkompensasi akan terjadi apabila pembebanan yang diberikan pada latihan tepat di atas ambang kepekaan (threshold) disertai dengan pemulihan (recovery) yang cukup. Apabila beban yang diberikan terlalu ringan tidak akan terjadi perubahan prestasi (plato), sedangkan pembebanan yang terlalu berat berakibat merosotnya penampilan atau involusi yang berakibat terjadinya overtraning.

2) Prinsip kembali keasal (Reversible) Menurut Djoko Pekik (2002:46) jika anda tidak menggunakan akan kehilangan, itulah filsafat dari prinsip reversible yang artinya adaptasi latihan yang telah dicapai akan berkurang bahkan hilang jika latihan tidak berkelanjutan dan tidak teratur yang berakibat terjadinya detraining (penurunan prestasi).

Hal tersebut akan mengganggu proses latihan karena pemborosan waktu, tenaga,usia,dan kemampuan yang telah dicapai bahkan apabila tidak dilatih kembali maka akan mengembalkan pada kondisi semula (retraining) yang akan memerlukan waktu lama untuk kembali kekondisi puncak.

3) Prinsip kekhususan (specifity)

Menurut Djoko Pekik (2002:47)

falsafah prinsip kekhususan adalah SAID (Sepesific Adaption to Imposed Demand) artinya latihan hendaknya khusus sesuai dengan sasaran yang diinginkan. Kekhususan dalam latihan perlu mempertimbangkan :

a) Cabang olahraga, misalnya latihan untuk pemain sepakbola berbeda dengan latihan bola voli.

b) Peran olahraga, misalnya latihan penyerang sepakbola berbeda dengan pemain bertahan.

c) Sistem energi, latihan olahraga yang dominan dengan anaerobik berbeda dengan latihan aerobik. d) Pola gerak, setiap olahraga memiliki pola gerak yang berbeda meliputi skillanskill, open skill-close skill.

e) Keterlibatan otot, latihan diberikan pada otot atau sekelompok otot yang berperan dalam melakukan sejumlah tehnik dan cabang olahraga.

f) Komponen kebugaran atau biomotor yang berperan dalam setiap cabang olahraga.

Dalam dunia olahraga prestasi, proses latihan yang dilakukan untuk meraih prestasi merupakan suatu pekerjaan yang sangat unik dan penuh resiko. Dikatakan demikian karena objek dalam hal ini yaitu manusia, dimana manusia sebagai anak latih, namun tidak diperbolehkan diperlakukan seperti robot. Oleh karena itu agar tujuan latihan dapat tercapai dengan baik maka latihan harus berpedoman pada teori-teori latihan, prinsip latihan, dan metode latihan yang secara ilmiah telah diakui kebenarannya.

Menurut Bompa (1994) latihan adalah upaya seseorang untuk mempersiapkan dirinya untuk tujuan tertentu. Menurut Nossek (1982) latihan adalah suatu proses atau dinyatakan dengan kata lain periode waktu yang berlangsung selama beberapa tahun sampai atlet tersebut mencapai standar penampilan tinggi. Menurut Junusul Hairy (1989) latihan adalah proses yang sistematis dari berlatih atau bekerja, yang dilakukan dengan kian hari meningkat jumlah beban latihan atau pekerjaannya. Lebih lanjut Junusul Hairy (1989) menjelaskan bahwa salah satu yang paling penting dari latihan harus dilakukan secara berulang-ulang, dan meningkatkan kekuatan dan daya tahan otot yang diperlukan untuk pekerjaannya. Untuk dapat berlatih secara baik maka perlu diperhatikan pedoman umum dalam latihan yaitu :

1. Kekhususan

Latihan itu harus khusus. Untuk mahir dalam ketrampilan dalam cabang olahraga tertentu seseorang harus berlatih olahraga. Otot- otot yang sama digunakan dan dilatih sesuai dengan cabang olahraga tersebut.

2. Tambah beban

Untuk tidak menimbulkan kerusakan 
dan untuk mencapai derajat kekuatan yang tinggi beban harus dinaikan secara teratur.

3. Hari berat dan santai Harus berlatih berat dan diselingi oleh hari yang santai untuk pemulihan.

4. Latihan dan kelebihan latihan Dalam latihan beban harus ditingkatkan sedikit demi sedikit sampai mencapai maksimum.

5. Latihan dasar dan pencapaian puncak

Latihan beban harus dimulai dengan latihan dasar untuk mempersiapkan kondisi, beban latihan harus ditingkatkan.

6. Kembali asal

Setiap latihan kalau tidak dipelihara akan kembali ke keadaan semula. Oleh karena itu setiap atlet harus berlatih terus untuk memelihara kondisinya.

Beberapa faktor yang perlu diperhatikan dalam latihan :

1. Prinsip dasar latihan

2. Tahap-tahap latihan

3. Pemanasan, dan

4. Warming down dan cool down

\section{Kondisi Fisik}

Kondisi berasal dari kata "condition" (bahasa latin) yang berarti keadaan. Menurut Syafruddin (1992: 34) kondisi fisik adalah keadaan fisik dan psikis serta kesiapan seorang atlet terhadap tuntutan-tuntutan khusus suatu cabang olahraga. Kondisi fisik dapat mencapai titik optimal jika memulai latihan sejak usia dini dan dilakukan secara terus menerus dan berkelanjutan dengan berpedoman pada prinsip-prinsip dasar latihan. Status kondisi fisik seseorang dapat diketahui dengan cara penilaian yang berbentuk tes kemampuan. Tes ini dapat dilakukan di dalam labratorium dan di lapangan. Meskipun tes yang dilakukan di laboratorium memerlukan alatalat yang mahal, tetapi kedua tes tersebut hendaknya dilakukan agar hasil penilaian benar-benar objektif.

Kondisi fisik dapat mencapai titik optimal jika latihan dimulai sejak usia dini dan dilakukan secara terus menerus. Karena untuk mengembangkan kondisi fisik bukan merupakan pekerjaan yang mudah, harus mempunyai pelatih fisik yang mempunyai kualifikasi tertentu sehingga mampu membina pengembangan fisik atlet secara menyeluruh tanpa menimbulkan efek di kemudian hari. Kondisi fisik yang baik mempunyai beberapa keuntungan, di antaranya mampu dan mudah mempelajari keterampilan yang relatif sulit, tidak mudah lelah saat mengikuti latihan maupun pertandingan, program latihan dapat diselesaikan tanpa mempunyai banyak kendala serta dapat menyelesaikan latihan berat. Kondisi fisik sangat diperlukan oleh seorang atlet, karena tanpa didukung oleh kondisi fisik prima maka pencapaian prestasi puncak akan mengalami banyak kendala, dan mustahil dapat berprestasi tinggi.

\section{Komponen Kondisi Fisik}

Kondisi fisik adalah salah satu kesatuan utuh terdiri dari komponen- komponen yang tidak dapat dipisahkan begitu saja, baik peningkatan maupun pemeliharaannya. Artinya, bahwa didalam usaha peningkatan kondisi fisik maka seluruh komponen tersebut harus dikembangkan. Menurut Sajoto (1988: 57), bahwa komponen kondisi fisik meliputi:

\section{1) Kekuatan (strength)}

Secara fisiologis (ilmu faal)

kekuatan merupakan kemampuan otot mengatasi beban atau latihan, sedangkan secara fisikal (ilmu fisika) kekuatan merupakan hasil perkalian antara massa dengan percepatan (acceleration). Dapat juga dikatakan bahwa kekuatan merupakan kemampuan dasar kondisi fisik. Tanpa kekuatan orang tidak akan bisa melompat, menarik, mendorong, mengangkat, menahan, lari, dan sebagainya. Dalam arti lain bahwa kekuatan dibutuhkan dalm kebanyakan aktifitas fisik. Setiap cabang olahraga memerlukan kekuatan, beberapa banyak dan beberapa besar kekuatan yang di butuhkan serta jenis kekuatan mana yang diperlukan sangat tergantung kepada cabang olahraganya. Bentuk kekuatan yang diperlukan sangat tergantung kepada cabang olahraganya

\section{2) Kecepatan (speed)}

Kecepatan merupakan satu elemen kondisi fisik yang sangat penting. Secara fisiologis kecepatan diartikan sebagai 
kemampuan yang berdasarkan kelentukan (flexibility). Jonath dan Krempel (1981) mengatakan bahwa kecepatan adalah proses sistem persyaratan dan alat-alat otot untuk melakukan gerakan-gerakan dalam satu satuan waktu.

Kecepatan sangat tergantung dari kekuatan, karena tanpa kekuatan, kecepatan tidak dapat berkembang atau meningkat. Bila seorang atlet ingin mengembangkan atau meningkatkan kecepatannya maka dia harus mengembangkan kekuatan, karena kemampuan kecepatan yang di peroleh sangat tergantung dari impuls kekuatan dan merupakan produk dari masa tubuh dan kecepatan tubuh itu sendiri

\section{3) Kelincahan (Agality)}

Kelincahan adalah suatu kemampuan seseorang untuk mengubah arah dan posisi sesuai dengan situasi yang dikehendaki atau dihadapi dengan cara secepat mungkin. Kelincahan merupakan kemampuan untuk mengubah posisi dan arah tubuh dengan cepat secara tepat waktu ketika sedang bergerak tanpa kehilangan keseimbangan maupun kesadaran akan posisi tubuhnya.

Kelincahan yaitu salah satu komponen fisik yang banyak dipergunakan dalam olahraga sepakbola. Kelincahan pada umumnya didefinisikan sebagai kemampuan untuk mengubah arah secara efektif ,cepat dan tepat, sambil berlari hampir dalam keadaan penuh (dengan sekuat tenaga). Kelincahan terjadi alasannya yaitu gerakan tenaga yang sangat ekplosif. Besarnya tenaga ditentukan oleh kekuatan dari kontraksi di serabut otot. Kecepatan otot tergantung dari kekuatan dan kontraksi serabut otot. Kecepatan kontraksi otot tergantung dari daya rekat serabut-serabut otot dan kecepatan transmisi impuls saraf. Kedua hal ini merupakan pembawaan atau bersifat genetis, atlet tidak akan sanggup merubahnya.

\section{4) Daya tahan (endurance)}

Daya tahan merupakan kemampuan organisme tubuh untuk mengatasi kelelahan yang disebabkan oleh pembebanan dalam waktu yang relative lama. Daya tahan merupakan salah satu elemen kondisi fisik yang terpenting, oleh karena basis dari elemen-elemen kondisi fisik yang lain.
Ditinjau dari lamanya kerja Bompa (1994) daya tahan dibedakan menjadi: (a) Daya tahan jangka panjang: daya tahan yang diperlukan dalam aktivitas kerja dalam waktu lebih dari 8 menit kebutuhan energinya dipenuhi oleh sistem energi aerobik. (b) Daya tahan jangka menengah: merupakan aktivitas olahraga yang memerlukan waktu 2 sampai 6 menit yang kebutuhan energinya dipenuhi oleh sistem energi anaerobik laktit dan oksigen. (c) Daya tahan jangka pendek: aktivitas olahraga yang memerlukan waktu 45 detik sampai 2 menit yang pemenuhan energinya dipenuhi oleh sistem energi anaerobik laktit (ATP-PC) dan anaerobik laktit. (d) Daya tahan otot: kemampuan sekelompok otot atau seluruh otot untuk mengatasi beban latihan dalam jangka waktu tertentu. (e) Daya tahan kecepatan: kemampuan seseorang untuk melakukan serangkaian gerak dengan intensitas maksimal dalam jangka waktu yang lebih lama.

\section{Metodologi Latihan Fisik}

1) Metode latihan kontinyu (berkelanjutan)

Pada umumnya aktivitas dari metode latihan kontinu pemberian bebannya berlangsung lama, panjang pendeknya waktu pembebanan tergantung dari lamanya aktivitas cabang olahraga yang dilakukan Sukadiyanto (2011:69). Latihan ini juga sering disebut dengan lari jarak jauh, yang dimaksud dengan latihan ini adalah latihan berlari dengan kecepatan dan jarak yang ditentukan, tanpa waktu istirahat sampai seluruh jarak ditempuh. Fox and Mathews (1993) membagi latihan menjadi 2 cara, masing-masing adalah disebut continuous slow running dan continuous fast-running.

Latihan CSR biasanya jarak yang harus ditempuh adalah meliputi jarak antara 2-5 kali jarak lomba. Misalnya pelari 1 mil, maka mereka berlatih dengan jarak antara 25 mil. Dengan ketentuan bahwa intensitas latihan meliputi 70-75\% $H R R$ atau kira-kira 80-85\% HRmax.

Sedangkan latihan CFR, adalah latihan lari dengan fase yang lebih cepat dari latihan CSR, serta jarak yang ditempuh lebih pendek dan akibat kelelahan lebih awal dicapai. Misalnya pelari 1 mil, maka mereka 
berlatih dengan jarak $1 / 4$ mil. Dengan ketentuan bahwa intensitas latihan meliputi 80-90\% HRR atau 85-95\% HRmax

2) Metode latihan interval

Merupakan metode yang tepat untuk meningkatkan kualitas fisik para olahragawan. Pada metode latihan interval lebih mengutamakan pemberian waktu interval (istirahat/pemulihan) pada saat antar set. Sukadiyanto (2011:74) membagi latihan interval menjadi tiga macam: (1) latihan interval jangka panjang, Latihan interval jangka menengah, (3) latihan interval jangka pendek.

3) Metode fartlek

Menurut Sajoto (1988:213) fartlek adalah program latihan interval training yang tidak formal. Latihan ini termasuk fast dan slow running yang bergantian. fartlek adalah bentuk latihan yang dilakukan dengan lari jarak jauh seperti halnya pada cross country. Bentuk latihan ini berasal dari Swedia yang berarti speed play atau bermain-main dengan kecepatan, waktu, latihan tidak dibatasi tetapi atlet bebas melakukan latihan ini dengan berbagai variasi bentuk lari sesuai dengan medianya.

Banyak pelatih dan atlet memasukkan program latihan tersebut sebagai variasi dari latihan lari dalam intentitas tinggi, maupun variasi latihan interval. Walaupun para atlet bebas dalam melaksanakan latihannya tetapi secara periodik mereka harus mencapai tingkat intentitas yang tinggi. Fartlek biasanya dimulai dengan lari-lari lambat yang kemudian divariasi dengan sprint-sprint pendek yang intensif dan dengan lari jarak menengah dengan kecepatan konstan yang cukup tinggi.

\section{KESIMPULAN}

Pengabdian Penyuluhan di Klub Sepakbola Fortuna FC ini telah dapat dijalankan dengan baik dan tanpa halangan yang berarti. Dengan kerjasama tim pengabdian yang baik dan peran serta aktif dari penyuluh/narasumber dalam kegiatan pengabdian ini maka semuanya telah berjalan sesuai yang diharapkan dan harapannya dapat memberikan manfaat bagi mitra pengabdian masyarakat dalam peningkatan prestasinya.
Pengabdian yang di lakukan ini telah sampai pada tahapan dilaksanakannya kegiatan penyuluhan tentang pentingnya peningkatan VO2Max guna meningkatkan kondisi fisik pemain Sepakbola Fortuna FC dan untuk selanjutnya akan kami lanjutkan sampai laporan akhir pengabdian masyarakat.

\section{DAFTAR PUSTAKA}

Djoko Pekik. (2000). Panduan Latihan Kebugaran (Yang Efektif danAman).Yogyakarta: Lukman Offset.

Fitness and Health. Jakarta: PT Raja Grafindo Persada.

Giriwijoyo. Y.S. (1992). Ilmu Faal Olahraga. Bandung : FPOK IKIP. Bandung

Grosser Straischka . (2004). Latihan Fisik Olahraga "Conditiontraining" diterjemahkan oleh Paulus Levinus Pesurney. Koni

Harsono. (1988). Panduan Kepelatihan . Jakarta: KONI

Harsono. (2001). Latihan Kondisi Fisik. Bandung: Senarai Pustaka. Jakarta: Depdikbud.

Janssen G.J.M. (1993). Laktat-Laktat Denyut Nadi. Jakarta: Pustaka Utama Grafiti.

Jeanne Wiessem. (1992). Conditioning and menthodology of training, London:Publishing Company.

Jonath, Krempel. (1981). Theory of Training. Lagos : Pan African Press,Ltd.

Junusul Hairy. (1989). Fisiologi Olahraga Jilid 1. Jakarta: Depdikbud Dirjen Dikti P2LPTK.

Martens Reiner. (1990). Successful coaching (thrid edition). Champagin, Illinois:Leisure Press.

Muhammad Sajoto. (1988). Pembinaan Kondisi Fisik Dalam Olahraga. Jakarta: Departemen Pendidikan dan Kebudayaan Direktorat Jendral Pendidikan Tinggi Proyek Pengembangan Lembaga Pendidikan Tenaga Kependidikan.

Nossek, Josef. (1995). Theory of Training (Teori Umum Latihan). Penerjemah: 
Muhammad Furqon. Surakarta : Universitas Sebelas Maret.

Nossek. (1982). General Theory of Training. Lagos: Pan African Press Ltd.

Pate, Rotella \& Clenaghan, M.C. (1993). Dasar-Dasar Ilmiah Kepelatihan. (Alih Bahasa: Kasiyo Dwijowinoto). Semarang: IKIP Semarang Press.

Reilly Thomas. (ed.) (1996). Science and Soccer. London: E. \& F.N. Spon.

Sajoto. (1988). Pembinaan Kondisi fisik dalam olahraga. Jakarta: Depdikbud.

Sajoto. (1988). Pembinaan Kondisi fisik dalam Olahraga. Jakarta: Depdikbud.

Sharkey, Brian J. (2003). Kebugaran dan Kesehatan. Terjemahan Eri Desmarini.

Soekarman, R. (1991). Energi dan Sistem Energi Predominan Pada Olahraga.Jakarta: KONI Pusat.

Soekarman. (1987). Dasar Olahraga untuk Pembina, Pelatih dan Atlet. Jakarta: Inti Idayu Press.

Soewarno K. (2001). Gerakan Dasar Dan Teknik Dasar Sepakbola. Yogyakarta :FIK. UNY.

Sucipto dkk. (2000). Sepak Bola. Jakarta: Direktorat Jendral Pendidikan Dasar dan Menengah.

Sugiyanto. (1996). Perkembangan dan Belajar Motorik. Jakarta: Departemen Pendidikan dan Kebudayaan. Direktorat Jendral Pendidikan Dasar dan Menengah.

Sukadiyanto (2011). Pengantar Teori dan Metodologi Melatih Fisik. Bandung:Lubuk Agung

Sutrisno Hadi. (1991). Analisis Butir untuk Instrumen Angket, Tes dan Skala Nilai dengan BASICA. Yogyakarta: Andi Offset.

Yudha M. Saputra. (1999). Pengembangan Kegiatan Ko dan Ekstrakurikuler. 